\title{
ANALISIS STRATEGI PEMASARAN DALAM MENINGKATKAN VOLUME PENJUALAN SUSU FORMULA NUTRILON ROYAL (STUDI PADA PT. NUTRICIA INDONESIA SEJAHTERA CABANG LAMPUNG)
}

\author{
ANALYSIS OF MARKETING STRATEGIES IN INCREASING THE SALES \\ VOLUME OF NUTRILON ROYAL FORMULA MILK \\ (STUDY ON PT. NUTRICIA INDONESIA SEJAHTERA BRANCH LAMPUNG)
}

\author{
Oleh: \\ Soewito ${ }^{1}$ \\ Melan Susanty Purnamasari ${ }^{2}$ \\ Novita Dwi Jayanti ${ }^{3}$ \\ ${ }^{1}$ Pogram Studi Ilmu Administrasi Bisnis Universitas Bandar Lampung \\ ${ }^{2}$ Program Studi Administrasi Bisnis Universitas Tulang Bawang - Lampung \\ ${ }^{3}$ Program Studi Administrasi Bisnis Universitas Tulang Bawang - Lampung \\ e-Mail: soewito@gmail.com
}

\begin{abstract}
Problems to be sought answers in this study are the factors that exist in the company Strategy that includes Analysis of Marketing Strategies that can increase sales, in line with the problem then this research is conducted by using inductive method that is starting from the field or empirical facts obtained by plunging into the field.

The results showed that the strategy undertaken by PT. Nutricia Indonesia Sejahtera can be concluded that the company's position has not been maximized and the company's position has not Stability Strategy because seen on the achievement of sales and sales charts in each year is not optimal, Then it was suggested that PT.Nutricia Indonesia Sejahtera try to utilize market opportunity with exisfence of Competitor more and more, then the meed for more Marketing Strategy, and facilitate contomers and, make New and more Loyal customers know more about the company and also the products produced by PT. Nutricia Indonesia Sejahtera.
\end{abstract}

Keywords: marketing, marketing strategy, promotional mix.

\begin{abstract}
ABSTRAK
Masalah yang hendak dicari jawabannya dalam penelitian ini adalah faktor-faktor strategi yang ada pada perusahaan yang meliputi Analisis Strategi Pemasaran yang dapat meningkatkan penjualan, Sejalan dengan masalah tersebut maka penelitian ini dilaksanakan dengan
\end{abstract}


menggunakan metode Induktif yaitu dimulai dari Lapangan/Fakta empiris yang diperoleh dengan cara terjun ke Lapangan.

Hasil penelitian menunjukan bahwa Stategi yang dilakukan PT. Nutricia Indonesia Sejahtera dapat disimpulkan bahwa kinerja perusahaan belum maksimal dan posisi perusahaan belum Stability Strategi, karena dilihat pada hasil pencapaian penjualan dan grafik penjualan tiap tahunnya, Bedasarkan temuan tersebut maka diajukan saran supaya PT. Nutricia Indonesia Sejahtera berusaha memanfaatkan peluang pasar dengan adanya Competitor yang semakin banyak, maka perlu adanya Strategi pemasaran yang lebih memudahkan konsumen dan menjadikan konsumen New dan Konsumen loyal lebih mudah mengenal Perusahaan dan juga Produk-produk yang di hasilkan oleh PT.Nutricia Indonesia Sejahtera.

Kata kunci: pemasaran, strategi pemasaran, bauran promosi

\section{PENDAHULUAN}

\subsection{Latar Belakang}

Susu formula merupakan makanan bayi yang dikonsumsi setiap harinya dengan jumlah volume yang cukup tinggi dan memiliki kandungan zat-zat yang penting bagi bayi dengan komposisi yang sesuai.Seiring dengan perkembangan zaman,pertumbuhan industri susu di Indonesia setiap tahunnya mengalami peningkatan sebesar 20 persen, sedangkan pada katagori produksi susu batita mengalami pertumbuhan 25-30 persen pertahun.Omzet penjualan susu formula bayi mencapai sebesar 11 miliar dollar AS setiap tahunnya.

Jumlah ini sangat besar sehingga banyak produsen susu formula yang gencar melakukan pemasaran terhadap produknya. Dilihat dari prospek usaha yang cukup baik bagi pengelola industri susu formula maka semakin banyak produsen susu formula lanjutan dengan menggunakan merek lisensi dan beredar di indonesia.

Informasi mengenai susu formula yang diberikan oleh pihak produsen kepada konsumen,seringkali membimbangkan konsumen untuk memilih susu mana yang terbaik sehingga harus dilakukan pemilihan secara cermat dan teliti,sebab bila susu tersebut tidak cocok tehadap bayi dapat menimbulkan gangguan pada bayi.

Susu formula terbagi menjadi dua jenis yaitu susu formula bagi yang diperuntukkan bagi bayi berumur 0-6 bulan dan susu formula lanjutan 6-36 bulan. Susu formula bayi 0-6 bulan, biasa disebut PASI yaitu Pengganti Air Susu Ibu.

Pemberian ASI yang efektif bagi bayi sampai dengan umur satu tahun,maka susu formula lanjutan berfungsi sebagai kelanjutan susu formula bayi dan biasa juga disebut produk pendamping ASI.

Pemberian susu formula lanjutan dimaksudkan sebagai nutrisi tambahan agar dapat membantu proses pertumbuhan dan perkembangan otak pada bayi. Pemberian susu formula terhadap bayi memang tidak disarankan oleh pemerintah,terkecuali karena alasan khusus seperti ibu tidak dapat memberikan ASI disebabkan meninggal dunia,sakit keras dengan indikasi medis dan hambatan pemberian ASI karena kekurangan jumlah air susu yang dihasilkan atau mutunya tidak memenuhi syarat serta alasan ini banyak ibu bekerja sehingga 
tidak dapat memberikan ASI setiap saat terhadap bayinya.

Hal ini yang mengakibatkan terjadinya peningkatan konsumsi susu formula bubuk lanjutan bagi bayi setiap tahunnya di Indonesia. Perkembangan konsumsi susu bubuk formula lanjutan.

Saat ini banyaknya produsen susu yang bermunculan dalam persaingan susu formula lanjutan di Indonesia dengan strategi promosi yang dilakukan hamper relatif hampir sama untuk segmen pasar menengah atas membuat perusahaan memerlukan strategi promosi yang paling efektif dan efisien bagi penjual produk susu formula lanjutan Nutrilon Royal.sehingga dapat meningkatkan volume penjualan Nutrilon Royal dapat tetap tercapai. Tingkat penjualan rata-rata Nutrilon Royal dapat di lihat pada Tabel 2 :

Tabel 1. Data Rata-Rata Penjualan Susu Formula Nutrilon Royal Per Tahun 2016

\begin{tabular}{|l|c|c|c|}
\hline Bulan & $\begin{array}{c}\text { Target } \\
\text { (Pack) }\end{array}$ & $\begin{array}{c}\text { Real } \\
\text { (Pack) }\end{array}$ & $\begin{array}{c}\text { \% } \\
\text { Realisa } \\
\text { si }\end{array}$ \\
\hline Januari & 147.442 & 198.791 & 135 \\
\hline Februari & 151.907 & 145.907 & 96 \\
\hline Maret & 175.140 & 255.987 & 146 \\
\hline $\begin{array}{l}\text { Triwula } \\
\text { n 1 }\end{array}$ & $\mathbf{4 7 4 . 4 8 9}$ & $\mathbf{6 0 0 . 6 8 5}$ & $\mathbf{1 2 7}$ \\
\hline April & 175.508 & 140.267 & 80 \\
\hline Mei & 175.508 & 251.540 & 143 \\
\hline Juni & 176.615 & 235.468 & 133 \\
\hline $\begin{array}{l}\text { Triwula } \\
\text { n 2 }\end{array}$ & $\mathbf{5 2 7 . 6 3 1}$ & $\mathbf{6 2 7 . 2 7 5}$ & $\mathbf{1 9 9}$ \\
\hline Juli & 176.615 & 330.084 & 187 \\
\hline Agustus & 264.959 & 161.561 & 61 \\
\hline $\begin{array}{l}\text { Septemb } \\
\text { er }\end{array}$ & 113.434 & 140.905 & 124 \\
\hline $\begin{array}{l}\text { Triwula } \\
\text { n 3 }\end{array}$ & $\mathbf{5 5 4 . 9 1 7}$ & $\mathbf{6 3 2 . 5 5 0}$ & $\mathbf{1 1 4}$ \\
\hline Oktober & 154.860 & 308.629 & 199 \\
\hline
\end{tabular}

\begin{tabular}{|l|c|c|c|}
\hline $\begin{array}{l}\text { Novemb } \\
\text { er }\end{array}$ & 184.358 & 191.367 & 104 \\
\hline $\begin{array}{l}\text { Desembe } \\
\text { r }\end{array}$ & 251.540 & 175.508 & 143 \\
\hline $\begin{array}{l}\text { Total } \\
\text { (s/d Des } \\
\text { 2016) }\end{array}$ & $\begin{array}{c}\mathbf{1 . 8 9 6 . 2 5} \\
\mathbf{5}\end{array}$ & $\begin{array}{c}\mathbf{2 . 3 6 0 . 5 0} \\
\mathbf{6}\end{array}$ & $\mathbf{6 6 3}$ \\
\hline
\end{tabular}

Sumber : PT. Nutricia Indonesia Sejahtera,Februari 2017.

Mengenai himbauan atau kode internasional tentang pemasaran Pengganti Air Susu Ibu (PASI) yang dibuat oleh organisasi kesehatan dunia (World Health Organization/WHO).

Untuk produk yang secara langsung atau tidak langsung dapat mengganti peran ASI sebagai menu utama bayi, yaitu pada bayi usia 0-12 bulan, dihimbau untuk tidak melalukan promosi atau publikasi dalam bentuk apapun, sedangkan di Indonesia kode etik internasional ini diadopsi melalui Keputusan Menteri Kesehatan Nomor 237/Menkes/SK/IV/1997.

Dilihat berdasarkan himbauan yang ada, untuk susu formula bayi sulit untuk memberikan informasi atau keterangan yang jelas serta melakukan kegiatan promosi untuk meraih konsumen terhadap produk susu formula bayi yang akan ditawarkan kepada pihak konsumen sedangkan untuk formula lanjutan, pada Keputusan Menteri Kesehatan Nomor 237/Menkes/SK/IV/1997, menyatakan bahwa yang termasuk bayi yaitu antara 0 12 bulan, sehingga untuk susu formula lanjutan yang berlaku untuk bayi berumur 636 bulan, masih dikenakan akan peraturan pemerintah untuk 6 bulan pertama.

\subsection{TujuanPenelitian}

Berdasarkan latar belakang dan penelitian yang telah dirumuskan maka penelitian ini bertujuan untuk mengetahui strategi 
pemasaran yang dilaksanakan oleh PT. Nutricia Indonesia Sejahtera dalam meningkatkan volume penjualan Susu Formula Nutrilon Royal.

\subsection{RumusanMasalah}

1. Bagaimana Perumusan Strategi Pemasaran Nutrilon Royal yang telah dilakukan oleh PT. Nutricia Indonesia Sejahtera?

2. Faktor-Faktor apa yang menjadi penyusun Strategi Pemasaran Nutrilon Royal PT. Nutricia Indonesia Sejahtera?

\section{METODE PENELITIAN}

Data yang digunakan pada penelitian ini terdiri dari data primer dan data sekunder. Data primer dan Data sekunder merupakan sumber-sumber data informasi yang dikumpulkan untuk menjadi dasar kesimpulan dari sebuah penelitian. Meskipun pada hakikatnya pengertian keduannya sama-sama merupakan sumber daya, namun berbeda cara memperolehnya.

a. Data primer data yang diperoleh dari pengamatan langsung di lapangan, berupa data hasil wawancara dan pengisian kuisioner responden pilihan. Responden adalah pihak perusahaan yang terkait dengan penerapan promosi susu formula Nutrilon Royal di wilayah Bandar Lampung.

Kelebihan dari data primer adalah data lebih mencerminkan kebenaran berdasarkan dengan apa yang dilihat dan didengar langsung oleh peneliti. Kekurangan dari data primer adalah membutuhkan waktu yang relatife lama.

Data sekunder merupakan data pelengkap dari data primer, yaitu data-data yang didapat dari instansi terkait. Data sekunder ini juga diperoleh dari data yang dimiliki oleh perusahaan seperti gambaran umum perusahaan dan dokumen perusahaan, internet, dan lainnya.

Kelebihan dari data sekunder adalah waktu dan biaya yang dibutuhkan untuk penelitian untuk mengklasifikasi permasalahan dan mengevaluasi data,relative lebih sedikit dibandingan dengan pengumpulan data primer. Kekurangan dari data sekunder adalah jika sumber data terjadi kesalahan , kadaluarsa atau sudah tidak relevan dapat mempengaruhi hasil penelitian

\section{LANDASAN TEORI}

\subsection{Pemasaran}

Pemasaran merupakan salah satu kegiatan pokok yang perlu dilakukan oleh perusahaan baik itu perusahan barang atau jasa dalam upaya untuk mempertahankan kelangsungan hidup usahanya. Hal tersebut disebabkan karena pemasaran merupakan salah satu kegiatan perusahaan, di mana secara langsung berhubungan dengan konsumen. Maka kegiatan pemasaran dapat diartikan sebagai kegiatan manusia yang berlangsung dalam kaitan dengan pasar.

Kotler mengemukakan definisi pemasaran berarti bekerja dengan pasar sasaran untuk mewujudkan pertukaran yang potensial dengan maksud memuaskan kebutuhan dan keinginan manusia. Sehingga dapat dikatakan bahwa keberhasilan pemasaran merupakan kunci kesuksesan dari suatu perusahaan (Kotler, 2001).

Menurut Stanton, definisi pemasaran adalah suatu sistem keseluruhan dari kegiatankegiatan bisnis yang ditujukan untuk merencanakan, menentukan harga, mempromosikan dan mendistribusikan barang atau jasa yang memuaskan kebutuhan baik kepada pembeli yang ada maupun pembeli potensial (Stanton, 2001). 
Menurut William J.Stanton definisi pemasaran merupakan system keseluruhan dari berbagai kegiatan bisnis atau usaha yang ditujukan untuk merencanakan, menentukan harga barang atau jasa, mempromosikannya, dan mendistribusikannya kepada kosumen dan bisa memuaskan konsumen. Dari definisi tersebut di atas, dapat ditarik kesimpulan bahwa pemasarn merupakan usaha terpadu untuk menggabungkan rencana-rencana strategi yang diarahkan kepada usaha usaha pemuas kebutuhan dan keinginan konsum untuk memperoleh keuntungan yang diharapkan melalui proses pertukaran atau transaksi (William J.Stanton, 2001).

Kegiatan pemasaran perusahaan harus dapat memberikan kepuasan kepada konsumen bila ingin mendapatkan tanggapan yang baik dari konsumen. Perusahaan harus secara penuh tanggung jawab tentang kepuasan produk yang ditawarkan tersebut. Dengan demikian, maka segala aktivitas perusaahan,harusnya diarahkan untuk dapat memuaskan konsumen yang pada akhirnya bertujuan untuk memperoleh laba.

Berdasarkan pengertian-pengertian di atas, dapat diambil suatu kesimpulan bahwa pemasaran adalah seluruh kegiatan yang bertujuan untuk memperlancar arus penyampaian barang dan jasa dari produsen kepada konsumen untuk memuaskan kebutuhan konsumen serta untuk mencapai tujuan perusahaan. Uraian di atas mengandung arti yang dapat dijelaskan berikut ini:

a. Adanya kegiatan manusia

Bahwa kegiatan pemasaran hanya dilakukan oleh manusia tidak seperti kegiatan konsumsi dan produksi yang dapat dilakukan oleh manusia/hewan. b. Untuk memperlancar serta menyempurnakan pertukaran yang mengandung:

1) Transaksi yang menunjukkan adanya satu kali pertukaran tanpa adanya implikasi apa-apa yang menyebabkan adanya hubungan yang lebih lama.

2) Hubungan pertukaran yaitu menunjukkan adanya hubungan dan terus menerus di dalam pertukaran.

c. Apa yang dipertukarkan

Pertukaran ini bukan hanya menyangkut barang, jasa dan uang tetapi termasuk juga mengenai perhatian, energi waktu sehingga yang dipertukarkan merupakan suatu yang mempunyai nilai bagi pembeli.

d. Adanya penjual dan pembeli

Hubungan pertukaran akan selalu disertai dua masalah nilai dan tergantung dari mana menilainya apakah pemilik atau uang.

\subsection{Konsep Pemasaran}

Pemasaran merupakan faktor penting untuk mencapai sukses bagi perusahaan akan mengetahui adanya cara dan falsafah yang terlibat didalamnya. Cara fan falsafah baru ini disebut konsep pemasaran (marketing concept). Konsep pemasaran tersebut dibuat dengan menggunakan tiga faktor dasar yaitu :

1. Saluran perencanaan dan kegiatan perusahaan harus berorientasi pada konsumen/pasar.

2. Volume penjualan yang menguntungkan harus menjadi tujuan perusahaan,dan bukannya volume untuk kepentingan volume itu sendiri.

3. Seluruh kegiatan pemasaran dalam perusahaan harus dokoordinasiakan dan diintegrasikan secara organisasi.

Menurut Swastha dan Irawan, konsep pemasaran sebuah falsafah bisnis yang 
menyatakan bahwa pemuasan kebutuhan konsumen merupakan syarat ekonomi dan sosial bagi kelangsungan hidup perusahaan. Bagian pemasaran pada suatu perusahaan memegang peranan yang sangat penting dalam rangka mencapai besarnya volume penjulan, karena dengan tercapainya sejumlah volume penjualan yang diinginkan berarti kinerja bagian pemasaran dalam tujuan utama. Konsep pemasaran adalah melayani konsumen dengan mendapatkan jumlah laba,atau dapat diartikan sebagai perbandingan antara penghasilan dengan biaya yang layak (Swastha dan Irawan, 2005:10).

Ini berbeda dengan konsep penjual yang menitik beratkan pada keinginan perusahaan. Falsafah dalam pendekatan penjualan adalah memproduksi sebuah pabrik, kemudian meyakinkan konsumen agar bersedia membelinya.Sedangkan pendekatan konsep pemasaran menghendaki agar menejemen menentukan keinginan konsumen terlebih dahulu, setelah itu baru melakukan bagaimana caranya memuaskan konsumen.

Menurut Basu Swastha dan Hani Handoko (2000:6) bahwa sehubungan dengan hal ini dengan mengemukakan"Konsep pemasaran adalah sebuah falsafah bisnis yang menyatakan bahwa pemuasan kebutuhan konsumen merupakan syarat ekonomi dan social bagi kelangsungan hidup dicapai dengan usaha mengenal dan merumuskan keinginan dan kebutuhsn konsumen. Perusahaan dalam memenuhi keinginan dan kebutuhan konsumen harus menyusun kebijakan produk, harga, promosi, dan distribusi yang tepat sesuai dengan keadaan konsumen sasaranya. Organisasi perusahaan yang menerapkan konsep pemasaran ini disebut organisasi pemasaran berdasarkan penjabaran pengertian di atas dan merujuk pada pendapat para ahli, inti dari konsep pemasaran yakni:

a. Kebutuhan-Konsep paling pokok yang melandasi pemasaran adalah kebutuhan manusia. Kebutuhan adalah suatu keadaan perasaan yang membutuhkan pemenuhan terhadap yang membutuhkan pemenuhan terhadap sesuatu seperti makanan, pakaian, perumahan, harga diri, rasa aman, dan kasih.

b. Pertukaran - Pemasaran terjadi apabila orang memutuskan untuk memenuhi kebutuhan dan keinginannya melalui pertukaran. Pertukaran adalah kegiatan untuk memperoleh barang/jasa yang diinginkan dari pihak lain dengan memberikan sesuatu sebagai gantinya.

c. Transaksi -Transaksi mengandalkan adanya nila-nilai yang dipertukarkan diantara dua pihak. Transaksi melibatkan sedikitnya dua barang atau jasa yang bernilai, syarat-syarat yang disepakati, waktu kesepakatan dan tempat kesepakatan.

d. Pasar- Konsep transaksi mengarah pada konsep pasar. Pasar adalah himpunan pembeli nyata dan pembeli potensi atas suatu produk.

Menurut Kotler dan Armstrong (2012 : 10) Konsep pemasaran yaitu, memahami apa yang dibutuhkan oleh konsumen dengan memberikan produk yang tepat bagi kebutuhan konsumen bukan mencari konsumen yang tepat untuk produk anda.

Dalam pemasaran terdapat enam konsep yang merupakan dasar pelaksanaan kegiatan pemasaran suatu organisasi (Kotler;2005:15) :

1. Konsep Produksi

Konsep produksi berpendapat bahwa konsumen didistribusi dengan luas. Disini tugas manajemen adalah memproduksi barang sebanyak 
mungkin. Karena konsumen dianggap akan menerima produk yang tersedia secara luas dengan daya beli mereka.

2. Konsep Produk

Konsep ini mengatakan bahwa konsumen akan menyukai produk yang menawarkan mutu, performasi dan cirri-ciri yang terbaik. Tugas manajemen disini adalah membuat produk berkualitas karena konsumen dianggap menyukai produk berkualitas tinggi dalam penampilan dengan ciriciri terbaik.

3. Konsep Penjualan

Konsep ini berpendapat bahwa konsumen dibiarkan begitu saja maka organisasi harus berupaya melaksanakan penjualan dan promosi yang agresif.

4. Konsep Pemasaran

Konsep ini mengatakan bahwa kunci untuk mencapai tujuan organisasi terdiri dari penentuan kebutuhan dan keinginan pasar sasaran serta memberikan kepuasan yang diharapkan serta lebih efektif dan efisien dibandingkan para pesaing.

5. Konsep Pemasaran Sosial

Konsep ini berpendapat bahwa tugas organisasi adalah menentukan kebutuhan, keinginan dan kepentingan pasar sasaran serta memberikan kepuasan yang diharapkan dengan cara yang lebih efektif dan efisien dari pada para pesaing dengan tetap melestarikan atau meningkatkan kesejahteraan konsumen dan masyarakat.

6. Konsep Pemasaran Global

Pada konsep global ini, manajer eksekutif berupaya memahami semua faktor-faktor lingkungan yang mempengaruhi pemasaran melalui manajemen strategis yang mmantap. Tujuan akhirnya adalah berupaya untuk memenuhi keinginan semua pihak yang terlihat dalam perusahaan.
Pemasaran tidak hanya mengenai penjualan atau peningkat volume penjualan, tetapi lebih jauh dari itu, adalah menyampaikan nilai kepada konsumen, sehingga diharapkan konsumen akan mengembalikan dalam bentuk nilai yang lain. Melayani pelanggan dengan memberikan manfaaat dsar dari produk yang dihasilkan dengan tujuan ovolusi pemasaran.

Definisi tersebut dapat disimpulkan bahwa tujuan dari konseppemasaran adalah memberikan kepuasan terhadap keinginan dankebutuhan konsumen. Konsep pemasaran tersebut dapat dicapaidengan usaha mengenal dan merumuskan keinginan dan kebutuhankonsumen. Perusahaan dalam memenuhi keinginan dan kebutuhankonsumen harus menyusun kebijaksanaan produk, harga, promosidan distribusi yang tepat sesuai dengan keadaan konsumensasarannya.

\subsection{TujuanPemasaran}

Volume penjualan yang menguntungkan merupakan tujuan pemasaran, artinya laba dapat diperoleh melalui pemuasan konsumen. Laba dapat membuat perusahaan tumbuh dan berkembang, menggunakan kemampuan yang lebih besar kepada konsumen serta memperkuat kondisi perekonomian secara keseluruhan. Laba merupakan tujuan umum dari perusahaan, Tujuan pemasaran merupakan wujud rencana yang terencana yang terarah di bidang pemasaran untuk memperoleh suatu hasilyang optimal.

Menurut Radiosunu (2001:27), strategi pemasaran didasarkan atas dua konsep sebagai berikut :

a. Segmentasi pasar. Tiap pasar terdiri dari bermacam-macam pembeli yang mempunyai kebutuhan, kebiasaan 
membeli dan reaksi yang berbedabeda.Perusahaan tak mungkin dapat memenuhi kebutuhan semua pembeli. Karena itu perusahaan harus mengelompok-kelompokan pasar yang bersifat heterogenke dalam satuansatuan pasar yang bersifat homogeny.

b. Market positioning. Perusahaan tak mungkin dapat menguasai pasar keseluruhan. Maka prinsip strategi pemasaran kedua adalah memilih pola spesifik pemusatan pasar yang akan memberikan kesempatan maksimumKepada perusahaan untuk mendapatkan kedudukan yang kuat. Dengan kata lain perusahaan harus memilih segmen pasar yang dapat menghasilkan penjualan dan laba yang paling besar.

\subsection{Perencanaan Strategi Pemasaran}

Setiap perusahaan selalu melaksanakan operasional aktivitasnya,yang didahului dengan membuat rencana, bagi kelangsungan dan pertumbuhan jangka panjang, yang didasarkan pada situasi,peluang,tujuan, dan sumber dayanya.

Kotler dan Armstrong (2008) mengemukakan :

"Perencanaan strategi adalah proses mengembangkan dan mempertahankan kecocokan strategi antara tujuan dan kemampuan organisasi serta peluang pemasaran yang sedang berubah."

D. Saladin (2004) menyatakan :

"Perencanaan strategi adalah suatu perencanaan ke depan yang ditetapkan untuk dijadikan pegangan, mulai dari tingkah korporet sampai pada tingkat unit bisnis, produk, dan situasi pasar."

Robert N. Anthony menyatakan :
"Perencanaan strategi adalah proses memutuskan program-program yang akan dilaksakan oleh organisasi dan perkiraan jumlah sumber daya yang akan dialokasikan ke setiap program selama beberapa tahun depan.

Dapat disimpulakan bahwa Perencanaan strategi merupakan langkah awal untuk menyelenggarakan manajemen strategi perusahaan. Perencanaan strategi untuk memanfaatkan berbagai peluang yang dapat diraih dan sebagai landasan untuk memonitor perubahan-perubahan yang terjadi sehingga dapat dilakukan penyesuaian.

Dalam pemasaran,perencanaan strategi terjadi pada tingkatan unit bisnis,produk, dan pasar. Perencanaan strategi pemasaran ini merupakan tulang punggung bagi perencanaan strategi perusahaan

\subsection{Langkah-langkah Perencanaan Strategi}

Kotler dan Armstrong (2008) menggambarkan langkah-langkah perencanaan strategi sebagai berikut.

Gambar 1. Langkah-Langkah Perencanaan Strategi

\begin{tabular}{|l|l|l|}
\hline $\begin{array}{l}\text { Mendefinisikan } \\
\text { misi } \\
\text { perusahaan }\end{array}$ & & $\begin{array}{l}\text { Menetapkan } \\
\text { tujuan dan sasaran } \\
\text { perusahaanan }\end{array}$ \\
\hline
\end{tabular}

Penjelasan :

1. Mendefinisikan misi perusahaan

Langkah awal mengembangkan pertanyaan misi, yaitu pernyataan tujuan perusahaan tentang tujuan yang ingin diperoleh perusahaan dalam lingkungan yang lebih besar.

Pernyataan tersebut harus berorientasi pasar dan didefinisikan berdasarkan kebutuhan pelanggan, Misi perusahaan harus dapat memuaskan kebutuhan 
pelanggan,Penyampaian misi ini hendaknya tidak terlalu sempit tetapi juga tidak terlalu luas

2. Menentukan tujuan dan sasaran perusahaan

Misi perusahaan harus dijabarkan menjadi tujuan-tujuan yang diperinci untuk setiap tingkat manajemen. Tujuan perusahaan ini mencakup tujuan bisnis dan tujuan fungsional, Tujuan bisnis adalah mengembangkan produk yang lebih baik sesuai dengan kebutuhan dan keinginan pelanggan, Adapun tujuan fungsional adalah menjalankan proses produksi secara efisien. Tujuan-tujuan tersebut menjadi tujuan pemasaran saat ini, untuk selanjutkan merancang strategi yang andal.

3. Merencang portofolio bisnis

Portofolio bisnis adalah kumpulan bisnis dan produk yang membentuk perusahaan. Portofolio bisnis harus sesuai dengan kekuatan dan kelemahan perusahaan untuk meraih peluang bisnis.

Perencanaan portofolio bisnis terdiri atas dua tahap,yaitu :

a. Perusahaan harus menganalisis portofolio bisnis terkini yang memiliki peluang bagi perusahaan untuk lebih berkembang dan memutuskan bisnis yang harus mendapatkan perhatian utama dan bisnis yang kurang menguntungkan;

b. Perusahaan harus membentuk portofolio masa depan dengan mengembangkan strategi pertumbuhan dan pengurangan.

4. Merencankan pemasran dan strategi fungsional lain

Langkah terakhir dalam perencanaan strategi adalah analisis portofolio,yaitu proses yang digunakan manajemen untuk mengevaluasi produk dan bisnis perusahaan. Dengan kata lain,pertamatama,manajer menyusun Strategi Bisnis Unit (SBU). Strategi Bisnis Unit (SBU) adalah unit perusahaan yang mempunyai misi dan tujuan terpisah serta dapat direncanakan serta independen dan bisnis perusahaan lain.

\section{ANALISIS DAN PEMBAHASAN}

PT. Nutricia Indonesia Sejahtera menghadapi persaingan yang cukup ketat dari para pesaing dalam segi pemasaran susu formula. Prioritas pemilihan susu formula oleh konsumen akan berbeda-beda tergantung pada sikap dan perilaku konsumen. Segmen pasar Susu Formula Nutrilon Royal merupakan masyarakat ekonomi menengah ke atas, sebab Susu Formula Nutrilon Royal merupakan kategori susu premium. Perilaku konsumen dalam melakukan pembelian Susu Formula Nutrilon Royal dapat dipengaruhi oleh kekuatan sosial budaya, misalnya pengaruh orang lain terhadap keputusan membeli, motivasi untuk menuruti pendapat orang lain, serta kekuatan psikologi, termasuk di dalamnya strategi promosi yang dilakukan perusahaan.

Pelaksanaan kegiatan pemasaran merupakan salah satu usaha penting dalam mencapai tujuan perusahaan yaitu mencapai laba maksimum. Tercapai tidaknya tujuan itu tergantung pada kemampuan perusahaan di bidang produksi dan pemasarannya. Perkembangan pasar yang penuh ketidakpastian menuntut setiap perusahaan yang ada untuk siap mengantisipasi dan menyesuaikan setiap perubahan dan fenomena yang terjadi. salah satu kegiatan pemaran yang paling penting adalah program promosi yang dijalankan perusahaan. 
Program promosi adalah program yang selalu menjadi perhatian produsen dalam meningkatkan penjualan. Namun dalam banyak prakteknya, banyak sekali program promosi yang seringkali tidak sesuai dengan terget pasar. Selain harus mempertimbangkan budget juga harus melihat karakter produk yang sedang dikreasi oleh seorang produsen.

Dalam penelitian ini, pembahasan mengenai strategi pemasaran yang dilakukan oleh PT. Nutricia Indonesia Sejahtera dalam meningkatkan volume penjualan Susu Formula Nutrilon Royal dilakukan melalui kegiatan bauran promosi

1. Free Tester/Sampling

Masyarakat pada umumnya sangat tertarik dengan adanya promosi penjualan yang menawarkan produk melalui pemberian potongan harga, kupon, diskon dan sampel produk.

Pemberian sampel susu formula Nutricia secara gratis sangat menarik minat konsumen untuk membeli Susu Formula Nutrilon Royal. Pembagian sampel atau free tester ini dilakukan pada saat diadakannya acara/event tertentu. Namun kelemahannya adalah kegiatan ini tidak banyak diketahui oleh konsumen dan hanya dilakukan pada saat-saat tertentu saja.

2. Acara/Event

Acara/event yang dilakukan PT. Nutricia Indonesia Sejahtera adalah dengan kegiatan seminar, acara/event promo bekerja sama dengan mall-mall terkemuka dan kegiatan lain seperti acara menggambar oleh anak dan lainlain. Acara/event yang diselenggarakan ini dilakukan guna mendekatkan PT. Nutricia Indonesia Sejahtera dengan konsumennya sehingga melalui kegiatan ini diperoleh manfaat baik bagi perusahaan maupun konsumen untuk saling memperoleh informasi mengenai produk-produk PT Nutricia Indonesia Sejahtera. .

3. Point Reward dengan Menukarkan Struk Belanja.

Melalui program ini, konsumen dapat memanfaatkannya dengan menukar poin dari hasil pembelian produk Nutrilon Royal. Struk belanja tersebut dapat ditukarkan dengan hadiah-hadiah menarik seperti mainan anak, alat masak, voucher belanja, voucher kursus les, voucher Gramedia serta voucher liburan.

Namun sayangnya program point reward dengan menukarkan struk belanja ini hanya dapat dilakukan melalui website PT. Nutricia Indonesia Sejahtera, sedangkan masyarakat/konsumen sebagian besar tidak pernah mengakses website perusahaan sehingga konsumen kesulitan untuk menukarkan point rewardnya dan menjadikan program ini menjadi tidak efektif. Seharusnya program point reward dilakukan langsung di tempat konsumen melakukan pembelian sehingga konsumen tidak kesulitan untuk menukarkan point rewardnya dengan hadiah-hadiah yang disediakan.

4. Promosi Penjualan

Promosi penjualan (sales promotion) merupakan program dan penawaran khusus dalam jangka pendek yang dirancang untuk memikat para konsumen (kebanyakan langsung kepada konsumen akhir) yang terkait agar mengambil keputusan pembelian yang positif. Promosi ini seringkali menghabiskan banyak biaya, tetapi banyak yang menganggap bahwa 
pengaruhnya sangat besar terhadap keputusan konsumen.

Promosi penjualan yang dilakukan oleh PT. Nutricia Indonesia Sejahtera antara lain pemberian diskon harga Susu Nutrilon Royal yang dijual di outletoutlet yang menjual produknya, kemudian gimmick berhadiah untuk ibu dan anak pda saat event-event yang diadakan oleh PT. Nutricia Indonesia Sejahtera serta free tester guna menarik konsumen baru dalam mencoba Susu Nutrilon Royal.

Kelebihan dari program ini adalah adanya diskon produk Susu Nutrilon Royal sehingga konsumen dapat membeli susu lebih murah dari harga biasanya, kemudian melalui acara/event yang diselenggarakan dapat lebih mendekatkan hubungan antar produsen dan konsumen.

Sedangkan kelemahan dari program ini adalah bahwa kegiatan ini hanya diselenggarakan pada saat-saat tertentu saja dan kemudian banyak konsumen yang tidak mengetahui adanya program-program promosi penjualan pada saat promosi penjualan tersebut dilakukan.

5. Pemasaran Interaktif

a. Facebook dan Instagram

Banyak konsumen Nutrilon Royal yang mengetahui produk dari Facebook dan Instagram dan aktif menggunakan Facebook dan Instagram, merupakan media sosial online yang paling cocok untuk produk makanan. Facebook dan Instagram juga dipilih karena dianggap paling menarik dan paling lengkap, pertama untuk visualisasi karena adanya foto-foto produk yang jelas, kedua adanya penjelasan detil mengenai spek produk termasuk list harganya, ketiga adanya testimoni dan endorsement yang dapat menambah informasi dan meningkatkan keyakinan konsumen sebelum membeli produk Nutrilon Royal. Bentuk-bentuk strategi promosi yang harus diperhatikan dan ditingkatkan oleh Nutrilon Royal pada Instagram adalah perbaikan foto produk dengan food stylist/food photographer, peningkatan posting testimoni di Instagram, peningkatan posting endorsement di Instagram, penjelasan produk di Instagram harus jelas dan detil, perbaikan dalam hal frekuensi update/posting di Instagram yaitu Nutrilon Royal harus lebih aktif update di Facebook dan Instagram (lebih rutin/konsisten) serta posting harus diperbanyak, Nutrilon Royal harus menambah jumlah pertemanan dan follower di Facebook dan Instagram, penambahan desain/tema untuk Instagram Nutrilon Royal agar tampilan lebih cantik dan lebih rapi serta penambahan fakta-fakta tentang produk, peningkatan promo-promo di Instagram misalnya berupa promo tag photo dan giveaway, penggunaan hashtag tertentu di Instagram.

b. Website

Penggunaan website sangat baik untuk mengenalkan produk yang ditawarkan. PT. Nutricia Indonesia Sejahtera memiliki website untuk mengenalkan produknya yaitu dengan alamat : http://nutricia.co.id/. Di dalam website ini terdapat profil perusahaan, pengenalan tentang produk, inovasi produk pada PT. 
Nutricia Indonesia Sejahtera, karir serta berita dan kegiatan yang dilakukan oleh PT. Nutricia Indonesia Sejahtera di seluruh Indonesia.

Namun terdapat sisi kelemahan dari website bagi masyarakat. Sebagian besar masyarakat sangat jarang bahkan hampir tidak pernah sama sekali mengakses website di Internet, sehingga hal ini menjadi kelemahan yang mendasar dari penggunaan website.

c. Periklanan

Penggunaan iklan sangat efektif dalam strategi promosi penjualan produk susu Nutrilon Royal. Kelemahan dari strategi periklanan adalah budget yang tinggi sehingga strategi ini tidak dilakukan setiap saat. PT. Nutricia Indonesia Sejahtera biasanya menggunakan strategi promosi secara masif hanya pada saat pengenalan produk baru saja, sedangkan pada tahap pertumbuhan dan tahap dewasa, PT Nutricia Indonesia Sejahtera hanya pada saat-saat tertentu saja mengiklankan produknya terutama iklan di televisi.

Selanjutnya berdasarkan hasil pembahasan tersebut selanjutnya dapat dianalisis mengenai efektivitas kegiatan strategi bauran promosi yang dilakukan PT. Nutricia Royal Sejahtera dalam meningkatkan volume penjualan Susu Nutrilon Royal.

\section{KESIMPULAN DAN SARAN}

\subsection{Kesimpulan}

Berdasarkan hasil analisis dan pembahasan dapat disimpulkan beberapa hal sebagai berikut :
1. Target penjualan Susu Formula Nutrilon Royal per tri wulan pada PT. Nutricia Indonesia Sejahtera untuk wilayah Lampung selalu terealisasi. Di mana pencapaian tertinggi dihasilkan pada tri wulan pertama sebesar $127 \%$. Keberhasilan pencapaian target penjualan Susu Formula Nutrilon Royal ini tentunya merupakan keberhasilan PT Nutricia Indonesia Sejahtera dalam menerapkan strategi pemasaran khususnya melalui strategi bauran promosi yang dijalankan oleh perusahaan.

2. Strategi pemasaran yang dilakukan oleh PT. Nutricia Indonesia Sejahtera dalam meningkatkan volume penjualan Susu Formula Nutrilon Royal dilakukan melalui kegiatan bauran promosi sebagai berikut:

a. Free Tester/Sampling. Pemberian sampel susu formula Nutricia secara gratis sangat menarik minat konsumen untuk membeli Susu Formula Nutrilon Royal. Pembagian sampel atau free tester ini dilakukan pada saat diadakannya acara/event tertentu. Namun kelemahannya adalah kegiatan ini tidak banyak diketahui oleh konsumen dan hanya dilakukan pada saat-saat tertentu saja.

b. Acara/event. Acara/event yang dilakukan PT. Nutricia Indonesia Sejahtera adalah dengan kegiatan seminar, acara/event promo bekerja sama dengan mall-mall terkemuka dan kegiatan lain seperti acara menggambar oleh anak dan lainlain. Acara/event yang diselenggarakan ini dilakukan guna mendekatkan PT. Nutricia Indonesia Sejahtera dengan konsumennya sehingga melalui kegiatan ini diperoleh manfaat baik 
bagi perusahaan maupun konsumen untuk saling memperoleh informasi mengenai produk-produk PT. Nutricia Indonesia Sejahtera.

c. Point Reward dengan Menukarkan Struk Belanja.

Program ini adalah penukaran struk belanja guna mendapatkan point reward yang dapat ditukarkan dengan hadiah-hadiah menarik yang disediakan PT. Nutricia Indonesia Sejahtera. Sayangnya program point reward dengan menukarkan struk belanja ini hanya dapat dilakukan melalui website PT. Nutricia Indonesia Sejahtera, sedangkan masyarakat/konsumen sebagian besar tidak pernah mengakses website perusahaan sehingga konsumen kesulitan untuk menukarkan point rewardnya dan menjadikan program ini menjadi tidak efektif.

d. Promosi Penjualan

Promosi penjualan antara lain pemberian diskon harga, gimmick berhadiah untuk ibu dan anak pda saat event-event yang diadakan oleh PT. Nutricia Indonesia Sejahtera serta free tester guna menarik konsumen baru. Kelebihan dari program ini adalah adanya diskon produk Susu Nutrilon Royal sehingga konsumen dapat membeli susu lebih murah dari harga biasanya, kemudian melalui acara/event yang diselenggarakan dapat lebih mendekatkan hubungan antar produsen dan konsumen. Sedangkan kelemahan dari program ini adalah bahwa kegiatan ini hanya diselenggarakan pada saat-saat tertentu saja dan kemudian banyak konsumen yang tidak mengetahui adanya program-program promosi penjualan pada saat promosi penjualan tersebut dilakukan.

e. Pemasaran Interaktif
Pemasaran interaktif melalui facebook dan instagram hanya berpengaruh terhadap konsumen yang aktif di sosial media. Sementara bagi konsumen yang tidak aktif di sosial media mereka tidak mengetahui mengenai informasi-informasi yang ada mengenai produk Susu Nutrilon Royal. Demikian halnya dengan keberadaan website PT. Nutricia Indonesia Sejahtera yang kurang mendapat akses dari masyarakat. Pemasaran interaktif lebih efektif dilakukan melalui strategi periklanan terutama melalui televisi. Kelemahan dari strategi periklanan adalah budget yang tinggi sehingga strategi ini tidak dilakukan setiap saat oleh PT. Nutricia Indonesia Sejahtera.

\subsection{Saran}

Berdasarkan hasil analisis dan pembahasan dapat disimpulkan beberapa hal sebagai berikut :

1. Target penjualan Susu Formula Nutrilon Royal per tri wulan pada PT. Nutricia Indonesia Sejahtera untuk wilayah Lampung selalu terealisasi. Di mana pencapaian tertinggi dihasilkan pada tri wulan pertama sebesar $127 \%$. Keberhasilan pencapaian target penjualan Susu Formula Nutrilon Royal ini tentunya merupakan keberhasilan PT. Nutricia Indonesia Sejahtera dalam menerapkan strategi pemasaran khususnya melalui strategi bauran promosi yang dijalankan oleh perusahaan.

e. Strategi pemasaran yang dilakukan oleh PT. Nutricia Indonesia Sejahtera dalam meningkatkan volume penjualan Susu Formula Nutrilon Royal dilakukan melalui kegiatan bauran promosi sebagai berikut: 
a. Free Tester/Sampling. Pemberian sampel susu formula Nutricia secara gratis sangat menarik minat konsumen untuk membeli Susu Formula Nutrilon Royal. Pembagian sampel atau free tester ini dilakukan pada saat diadakannya acara/event tertentu. Namun kelemahannya adalah kegiatan ini tidak banyak diketahui oleh konsumen dan hanya dilakukan pada saat-saat tertentu saja.

b. Acara/event. Acara/event yang dilakukan PT. Nutricia Indonesia Sejahtera adalah dengan kegiatan seminar, acara/event promo bekerja sama dengan mall-mall terkemuka dan kegiatan lain seperti acara menggambar oleh anak dan lainlain. Acara/event yang diselenggarakan ini dilakukan guna mendekatkan PT. Nutricia Indonesia Sejahtera dengan konsumennya sehingga melalui kegiatan ini diperoleh manfaat baik bagi perusahaan maupun konsumen untuk saling memperoleh informasi mengenai produk-produk PT. Nutricia Indonesia Sejahtera.

c. Point Reward dengan Menukarkan Struk Belanja.

Program ini adalah penukaran struk belanja guna mendapatkan point reward yang dapat ditukarkan dengan hadiah-hadiah menarik yang disediakan PT. Nutricia Indonesia Sejahtera. Sayangnya program point reward dengan menukarkan struk belanja ini hanya dapat dilakukan melalui website PT. Nutricia Indonesia Sejahtera, sedangkan masyarakat/konsumen sebagian besar tidak pernah mengakses website perusahaan sehingga konsumen kesulitan untuk menukarkan point rewardnya dan menjadikan program ini menjadi tidak efektif.

d. Promosi Penjualan

Promosi penjualan antara lain pemberian diskon harga, gimmick berhadiah untuk ibu dan anak pda saat event-event yang diadakan oleh PT. Nutricia Indonesia Sejahtera serta free tester guna menarik konsumen baru. Kelebihan dari program ini adalah adanya diskon produk Susu Nutrilon Royal sehingga konsumen dapat membeli susu lebih murah dari harga biasanya, kemudian melalui acara/event yang diselenggarakan dapat lebih mendekatkan hubungan antar produsen dan konsumen. Sedangkan kelemahan dari program ini adalah bahwa kegiatan ini hanya diselenggarakan pada saat-saat tertentu saja dan kemudian banyak konsumen yang tidak mengetahui adanya program-program promosi penjualan pada saat promosi penjualan tersebut dilakukan.

e. Pemasaran Interaktif

Pemasaran interaktif melalui facebook dan instagram hanya berpengaruh terhadap konsumen yang aktif di sosial media. Sementara bagi konsumen yang tidak aktif di sosial media mereka tidak mengetahui mengenai informasi-informasi yang ada mengenai produk Susu Nutrilon Royal. Demikian halnya dengan keberadaan website PT. Nutricia Indonesia Sejahtera yang kurang mendapat akses dari masyarakat. Pemasaran interaktif lebih efektif dilakukan melalui strategi periklanan terutama melalui televisi. Kelemahan dari strategi 
periklanan adalah budget yang tinggi sehingga strategi ini tidak dilakukan setiap saat oleh PT. Nutricia Indonesia Sejahtera.

\section{DAFTAR PUSTAKA}

www.nutricia.co.id

Anonim. 24 Juli 2007. Nutrition.Infant Formula Basics

Anonom. 1997. Pemasaran Pengganti Air Susu Ibu. Kepmenkes. Jakarta

A., Hiam and C.D. Schewe. 1994. The Portable MBA Pemasaran. Jakarta: Binarupa Aksara

Afif, Faisal. 1999. Psikologi Penjualan. Bandung ; Angkasa.

Berkowitz.1992. Marketing. Richard Irwin, Inc.

J.P., Guiltiman and Paul G.P.1990. Marketing Management,Strategies and Programs.

McGraw-Hill Book,Inc.

Hill, W.L. Charles dan Jones R. Gareth. 1989. Management Strategic Printed in the USA.

Kotler and Kotler. 2006. Marketing Managemen. New Yerseg.

Darmawan, Daidumi dkk. 1990. Dasardasar Marketing. Bandung: Lembaga Manajemen Ekonomi UNPAD.

Lexy J. Moleong, Metodologi Penelitian Kualitatif, Bandung: PT. Remaja Rosdakarya, 2009.

Hill, W.L. Charles dan Jones R. Gareth. 1989. Management Strategic. Printed in USA.

J.P. Guiltiman dan Paul G.P. 1990. Marketing Management, Strategies and Programs.

Kotler, Philip. 2000. Manajemen Pemasaran di Indonesia. Salemba Empat. Jakarta.

Kotler, Philip. 2001. Manajemen Pemasaran : Analisis,
Perencanaan, Implementsi. PT Prenhalindo. Jakarta.

Kotler, Philip dan Garry Armstrong. 2008. Prinsip-prinsip Pemasaran. Jilid I. Erlangga. Jakarta.

Miintzberg, Henry dan James Brian Quinn. 1995. The Strategy Process: Concepts Contex, Case 2. Prentice Hall. New Jersey.

Radiosunu. 1993. Manajemen Pemasaran: Suatu Pendekatan Analisis. Edisi kedua. BPFE. Yogyakarta.

Stanton, William J. 2001. Prinsip-prinsip Pemasaran. Jilid 7. Erlangga. Jakarta.

Swastha, Basu, Irawan. 2005. Manajemen Pemasaran Modern. Liberty. Yogyakarta 